Wong, S.W. \& Yuen, M. (2013). General values and work values of social work students in Hong Kong. Hong Kong Journal of Social Work, 47(1/2), 19-34. DOI: 10.1142/\$0219246213000041

\title{
General Values and Work Values of Social Work Students in Hong Kong
}

\author{
Shui-wai Wong
}

Mantak Yuen

Shui-wai Wong: Department of Applied Social Sciences, Hong Kong Polytechnic University, Hung Hom, Hong Kong, China;

MantakYuen: Center for Advancement in Inclusive and Special Education, Faculty of Education, University of Hong Kong, Pokfulam Road, Hong Kong, China.

Correspondence concerned this article should be addressed to Shui-wai Wong, Department of Applied Social Sciences, Hong Kong Polytechnic University, Hung Hom, Hong Kong, China E-mail: sswongsw@polyu.edu.hk

Shui-wai Wong is an instructor in the Hong Kong Polytechnic University. He is an experienced college counselor and has earned his Doctor of Education degree in the Faculty of Education at the University of Hong Kong. His professional interests include student counselling, work values and career inclination assessment.

Contact address: Dr. Shui-wai Wong, Department of Applied Social Sciences, the Hong Kong Polytechnic University, Hung Hom, Hong Kong.

Email: sswongsw@polyu.edu.hk

Mantak Yuen is an Associate Professor and Director of the Center for Advancement in Inclusive and Special Education within the Faculty of Education at the University of Hong Kong. He is a registered counseling and educational psychologist in Hong Kong. His professional interests are in social-cognitive theory, school counseling, gifted education, and life career development. He coordinates a postgraduate course in Career Education and Counseling. He is the leader of a research team examining life-skills development and connectedness among children and youth in relation to school guidance and counseling programs.

Contact address: Dr. Mantak Yuen, Center for Advancement in Inclusive and Special Education, Faculty of Education, University of Hong Kong, Pokfulam Road, Hong Kong, China. E-mail: mtyuen@hku.hk 


\title{
General Values and Work Values of Social Work Students in Hong Kong
}

\begin{abstract}
This paper reports research that examined general values and work values held by university students studying social work in Hong Kong. Results were compared with values held by similar students studying in different majors. Results indicated that social work students rated general values such as benevolence, self-direction, universalism and tradition higher than their non-social work counterparts. They also rated work values such as altruism, creativity, supervisory relations, independence and intellectual stimulation more highly. However, the social work students held lower values associated with economic returns, thus supporting a view that students with an inclination towards social work tend to espouse self-transcendence and intrinsic work values, and are less influenced by material rewards. Among the social work respondents, gender differences were found in both general and work values. Differences were also noted between the groups with different modes of study. Implications for social work education and future research are discussed.
\end{abstract}

\section{Keywords}

Chinese, general values, Hong Kong, social work students, work values 
Social work tends to be a profession that relies heavily on practitioners holding certain positive beliefs and values that must underpin the helping process (Barnard, 2008). For this reason, it is relevant for social work educators to understand more about the value systems developed by their current and graduating social work students who are due to join the profession in the near future.

\section{Values}

Values are described as being “...socially shared concepts of what is good, right, and desirable” (Knafo, Roccas, \& Sagiv, 2011, p.178). These values tend to govern people’s perceptions, predilections, attitudes, motivations, choices, decisions, and behaviours. It is possible to group values together in several ways - for example those related to operating as a member of society, those related to religious beliefs, family values, those related to politics, and so on. For the purposes of this paper, two related but separate constructs are identified, general values and work values (Lyons, 2003). General values are those that embrace freedom, wealth, meaning in life, social justice, and mature love, while work values relate specifically to autonomy, salary, prestige, supervisory relationship and job security. Values of both types are regarded as crucial in determining an individual's life choices and career decision-making (Brown \& Crace, 1996; Judge \& Bretz, 1992).

The study reported here focused on the general and work values held by social work students in Hong Kong, and compared these values with those held by students undertaking 
other majors.

\section{Rationale}

A good foundation for the systematic examination of human values is provided by Shalom

Schwartz's theory of universal human needs (Schwartz, 1996), and Donald Super's concept of work values (Super, 1995). The two instruments described below were used to collect data for this study.

Theory of universal human needs: Schwartz postulated that 10 discrete types of values form a human values system, in which some values are mutually compatible and others conflicting. The instrument known as Schwartz Values Survey (SVS) was constructed to tap the 10 general values of an individual (Schwartz, 1992). The types of values Schwartz identified were universalism (protection for the welfare of all; social justice; a world at peace), benevolence (maintaining and promoting the wellbeing of people; helpfulness; responsibility), tradition (respect for customs, tradition, culture and religion), conformity (compliance with social norms; self-discipline; obedience), security (safety and stability of society and self; family security; social order), power (prestige, high status and dominance over others; social power; authority), achievement (personal success; influence), hedonism (personal pleasure and gratification; enjoying life), stimulation (excitement, innovation, and challenge; varied life), and self-direction (free and independent thinking and action; creativity; independence).

In a circular structure depicting the value system (Figure 1), compatible values are 
situated nearby, whereas conflicting values are located at a distance. The 10 values together form 4 higher-level values, namely: openness to change (composed of stimulation and self-direction), conservation (tradition, conformity, and security), self-enhancement (composed of power, achievement, and hedonism), and self-transcendence (universalism and benevolence).

Schwartz's model has been supported empirically by research in 55 countries (Ros et al., 1999). In addition, a significant strength of the model is that values are conceptualized as an integrated, organized and coherent system, instead of simply a collection of unrelated individual values (Schwartz, 1996). Change in one value can lead to changes in other values, so as to maintain the integrity of the system as a whole (Bardi et al., 2009, cited in Bardi \& Goodwin, 2011).

Super's Concept of Work Values: Super (1995) drew upon earlier work by Ginzberg et al. (1951) to develop a Work Values Inventory (WVI). The instrument contains 15 subscales, each covering a separate cluster of values in the domain of work. The subscales can be classified under three major categories (described below), forming the basic structure of Super's concept of work values (Super, 1962).

1. Intrinsic work values - covering those related to striving for intrinsic satisfaction, or finding pleasure in work activities, namely: altruism, creativity, achievement, aesthetics, independence, management, and intellectual stimulation. 
2. Extrinsic work values - related to pursuing monetary rewards or prestige, namely: economic returns, security, prestige, and way of life

3. Concomitants - covering values related to working hard for social and environmental rewards: supervisory relations, surroundings, associates, and variety.

\section{Method}

Participants

Recruitment of respondents was on a voluntary basis, through invitation from the academic staff. A total of 99 social work students (69.7\% female) from four universities in Hong Kong participated in the study. Within this sample, 37.4\% were full-time Bachelor of Social Work (BSW) students, while the remaining were either part-time BSW (23.2\%) or part-time Master of Social Work (MSW) students (39.4\%). Ages ranged from 19 to 43 years, with a mean age of 26.2 years.

The 619 students from other majors were recruited by staff from both academic departments and student affairs offices through convenience sampling. Among them, 55.1\% were females. Age ranged from 18 to 28 with a mean of 20.8. Areas of study included business (24.9\%), engineering, mathematics, physical science (29.0\%), social and behavioural sciences (12.5\%), health care education (mainly nursing) (15.5\%), arts and humanities (17.1\%) and others (1.0\%). In terms of year of study, $42.5 \%$ were from Year One, 37.3\% from Year Two, and 20.2\% from Years Three and Four. Data from this group were used to allow analyses of 
differences in values held by social work and non-social work students.

Procedure

Participants were asked to complete the Schwartz Values Survey (SVS-58), the Work

Values Inventory (WVI), and provide basic personal information. Respondents were allowed to complete the questionnaires in their own time, and then return them anonymously to the researchers.

Measures

Schwartz Values Survey (SVS-58). General values were measured using a Chinese version of SVS-58 provided by Prof. Shalom Schwartz. The SVS-58 contains 2 lists of values items - 30 describing potentially desirable end-states in noun form, and the other 28 in adjective form. Each item represents a value defined by a short description. Respondents are required to rate each item on a 9-point scale. The scale ranges from -1 (opposed to my principles) to 0 (not important) through to 7 (of supreme importance) to indicate the degree of importance of each value as a guiding principle in their own life. In studies with adult samples in Australia, the instrument was found to have moderate internal consistency, with mean alphas of 0.67 across all value types (Scannell \& Allen, 2000).

Super's Work Values Inventory (WVI). The WVI is a 45-item scale measuring work values. Respondents are asked to indicate their degree of agreement or disagreement for each statement on a 5-point scale ranging from 1 (strongly disagree) to 5 (strongly agree). The scale 
contains the following 15 subscales of work values: intellectual stimulation, altruism, aesthetic, management, creativity, achievement, economic returns, prestige, security, supervisory relations, associates, surroundings, variety, and way of life. WVI has been widely used in research with students and with persons in various occupations, and its reliability and validity established (Neuman, Pizam, \& Reichl, 1980).

The Chinese version was translated by the authors; and its equivalence with the original was assessed by a social scientist and a clinical psychologist. Finally, it was back translated to English and compared to the original scale by two bilingual university English teachers.

Both the scales were validated using local samples by Wong (2013).

\section{Results and Discussion}

Psychometric Properties of SVS and WVI

Most of the SVS and WVI subscales were reliable, but those named as tradition, hedonism, achievement, way of life, and aesthetics were somewhat lacking in internal consistency (Table 1). As explained by Schwartz et al. (2001), it is not uncommon for values measures to have a low reliability coefficient because the scales usually have very few items per subscale, and these few items try to cover a number of different dimensions. For example: the single category 'universalism' encompasses diverse values such as 'understanding and tolerance', 'striving for justice', and 'concern for nature'. Similarly, 'Prestige' work values might include 'high social status', ‘good reputation' and 'high level of importance', making it 
difficult to establish consistency of measurement across the items. On this point, Schmitt (1996) argues that it is not prudent to judge a scale solely based on an arbitrary cut-off point, such as Cronbach’s Alpha value of 0.7. Merely looking at subscale mean scores can be misleading. Often in psycho-social and sociological research it is more important to consider the specific information that each separate item contributes to building up a total picture, rather than rejecting a subscale simply because of a lower Alpha.

The picture that emerged here when using Multidimensional Scaling technique was that the general values of social work students basically complied with Schwartz's theory. The SVS subscales were aligned in a circumplex structure, as postulated by Schwartz (1996), offering support for construct validity of SVS (Figure 2).

However, the work values structure for social work students in the present study was different from the intrinsic-extrinsic-concomitant typology suggested by Super (1962). Four factors (accounting for 67.1\% of total variance) were identified by Exploratory Factor Analysis with Varimax rotation. Factor 1 loaded on values attributed to creativity, management, aesthetics, prestige, independence, and variety. This factor could be termed "intrinsic work values”. Factor 2 included values associated with achievement, supervisory relations, altruism and intellectual stimulation, and could be titled "personal achievement and relationships". Factor 3 can be regarded as "extrinsic-concomitants" as it consisted of values associated with surroundings, associates and way of life. Factor 4 could be named as "economic returns and 
security”. Kaiser-Meyer-Olkin Measure of Sampling Adequacy was calculated to be 0.794, and Bartlett's Test of Sphericity was significant $(\mathrm{p}<0.000)$. The result was in line with a previous study that found the factor structure of WVI to be sample-dependent (Wong, 2013). General Values of Social Work Students in Hong Kong

A trend that was noted in subscale mean scores, where social work students scored high on the subscales of benevolence, self-direction, and universalism, but low on power, stimulation and tradition (Table 1). This result makes good practical sense, as social work students theoretically espouse self-transcendent values and, for example, have concern for preservation and enhancement of people’s welfare. Social workers respect individual's uniqueness and personal choice, and thus rate self-direction values highly, including freedom, independence, choosing own goals, and creativity. In contrast, social workers tend to place lower priority on self-enhancement values (such as power) which are incompatible with self-transcendence in Schwartz's theory. They have less concern for social status and prestige.

Closer examination the results of T-test shown in Table 1 reveals that social work students did score higher than the non-social work students in benevolence $(\mathrm{p}<0.01)$, self-direction $(\mathrm{p}<0.01)$ and universalism $(\mathrm{p}<0.001)$. A very interesting finding is that although social work students scored low in tradition values compared to benevolence, self-direction, and universalism, they actually had higher scores than the non-social-work students in tradition values ( $\mathrm{p}<0.01)$. Hence, compared to their counterparts, they are more accepting of the customs 
and ideas that traditional culture or religion offers.

Work Values of Social Work Students in Hong Kong

In terms of work values, social work students scored highest in the subscales of supervisory relations, altruism, and achievement. It is not surprising to find altruism and achievement ranked highly, because they embrace values that are essential in the helping professions. Altruism reflects the value attached to work that enables one to contribute to the welfare of others (White, 2005), while achievement places value on work that gives one the feeling of accomplishment (White, 2005). The highest score was in the subscale of supervisory relations. This probably reflects a cultural characteristic of Hong Kong Chinese students, who place great value on maintaining good inter-personal relationships, or "guanxi”, particularly relationships with superiors (Chu, 2008).

In contrast, work values associated with management (self-enhancement and social power), aesthetics, and variety were not rated as highly. Low ratings for values associated with aesthetics and variety suggest that social work students tend to place less value on making beautiful things at work and to accept repetitive tasks.

T-tests results in Table 1 show that social work students had higher scores than their non-social-work counterparts on WVI subscales of altruism $(\mathrm{p}<0.001)$, creativity $(\mathrm{p}<0.01)$, supervisory relations $(\mathrm{p}<0.05)$, independence $(\mathrm{p}<0.05)$, and intellectual stimulation $(\mathrm{p}<0.05)$, but lower scores on economic returns $(\mathrm{p}<0.05)$. These results seem to suggest that social work 
students espouse intrinsic work values while paying less attention to extrinsic values, such as obtaining material rewards.

Gender Differences in General and Work Values

T-tests showed that female social work students tended to rate higher than males in benevolence (SVS) $(\mathrm{p}<0.05)$, tradition (SVS) $(\mathrm{p}<0.05)$, achievement (WVI) $(\mathrm{p}<0.01)$, surroundings (WVI) $(\mathrm{p}<0.05)$, supervisory relations (WVI) $(\mathrm{p}<0.01)$, associates (WVI) $(\mathrm{p}<0.05)$, prestige $(\mathrm{WVI})(\mathrm{p}<0.05)$, independence $(\mathrm{WVI})(\mathrm{p}<0.05)$, and altruism (WVI) $(\mathrm{p}<0.01)$ (Table 2). The phenomenon of females scoring higher in benevolence is expected, and is similar to the findings of other studies reported in the literature (Ryckman \& Houston, 2003; Schwartz \& Rubel, 2005; Feather, 2004). However, the finding that females place higher value on tradition is contradictory to data from another study that suggests no gender differences (Schwartz \& Rubel, 2005). Other studies have suggested that females attach greater importance to achievement (Feather, 2004; Ryckman \& Houston, 2003); but in this study both sexes are found to have more or less the same achievement scores.

In terms of work values, the data here reveal more gender differences in WVI subscales than those reported in earlier studies by Miller (1974) and Zaccaria et al. (1972). Females in this study were inclined to place more importance on concomitants, such as surroundings, supervisory relations and associates. This echoes prior research findings that females are more relationship-oriented and environment-oriented than males (Pryor, 1983, as cited in Elizur, 1994). Previous research has also suggested that Western female students are more altruistic 
than males in their values (Hendrix \& Super, 1968; Miller, 1974; Staats, 1981). That view is supported here with evidence from Hong Kong Chinese females in the present study. In addition to support the often-cited conclusion that females are more altruistic, people-focused, and environment-focused, the present study has showed that female social work students also place greater emphasis on achievement, prestige, and independence than male counterpart. Perhaps, this may reflect that the female-dominated profession attracts females with high work aspiration.

Effect of Mode of Study on General and Work Values

Different modes of study reflect variations in a wide range of demographic, social and psychological variables, including age, level of educational attainment, stage of psycho-social development, work experience, and financial status and thus have differential effects of an individual's values. One-way ANOVA results indicate that there was no significant difference among the three social work programmes in general values (SVS). Statistical differences in work values (WVI) were reported, including way of life $(\mathrm{p}<0.05)$, associates $(\mathrm{p}<0.05)$, and variety $(\mathrm{p}<0.05)$ among the full-time BSW, part-time BSW and part-time MSW students. Based on the LSD Post Hoc test results, full-time BSW students had higher scores than both MSW and part-time BSW students in both way of life and associates values (see Table 3). It is speculated that being still in the early adulthood stage, full-time BSW respondents concern more about their peers and their own lifestyles. As for the Variety work values, MSW students 
were found to rate higher than both full-time and part-time BSW. Perhaps, MSW respondents had chosen programme different from their undergraduate majors reflecting their strong desire to try different kinds of work experiences in their future career development.

However, both the effects of gender and mode of study on values should be further examined in the future study with better research design and larger sample size.

\section{Implications for Social Work Education and Future Research}

Social work is a values-focused profession, and it is crucial for social work educators to understand their students’ values systems. In Hong Kong there is a lack of localized instruments to enable educators to conduct regular assessments in this values domain. This study has indicated that Chinese translations of Schwartz Values Survey (SVS) and the Work Values Inventory (WVI) offer viable options for studying general and work values of social work students in Hong Kong. The instruments may be equally applicable for assessing trainee’s values in other professions.

Although values are considered a reasonably stable construct, a few studies confirm that values (including work values) change over time (Jin \& Round, 2011; Seligman \& Katz, 1996). This can occur, for example, when students or trainees progress through courses that expose them to new ideas, and as they gain experience. Societal changes could also be related to values changes in students. SVS and WVI could be adopted in universities and colleges for examining students' changes in values over time. 
This study was an exploratory one, and has some limitations. The adoption of convenience sampling (non-random method) and relatively small sample size limits the degree to which findings can be generalized to other student groups.

The findings of the present study could be shared with the social work students, to help them reflect upon values and the role they play in influencing choices, decisions and daily practices. Social work teachers can help students explore how their values form, and how values will affect their social work practice.

The evidence that in Hong Kong social work students’ (particularly females) attach high importance to supervisory relations, may suggest a tendency for them to follow a superior's instruction so as to maintain a good relationship. This situation could be discussed in class, with students encouraged to think about, and resolve, dilemmas such as a conflict between following a superior's instructions and upholding social work principles and values.

At an individual level, social work students who score relatively high in tradition values (the acceptance of the customs and ideas that one's culture or religion imposes on the individual) should be challenged and reminded of their tendency to maintain status quo and to be conservative. In addition, their inclination to rate power and management values low should be explored the reasons behind. They should be encouraged to develop aspiration for taking up more administrative responsibility in their future work and becoming more influential in building a work setting which facilitates social work practice that upholds our core social work 
values, such as human worth, dignity, respect, personal caring and social justice. For social work educators, the most important work is to facilitate students better understand and clarify their own personal values and then further integrate both their own values with social work professional values. As such, they can excel in the values-based professional practice. 


\section{References}

Bardi, A. \& Goodwin, R. (2011). The dual route to value change: Individual processes and cultural moderators. Journal of Cross Cultural Psychology, 42, 271-287. doi:10.1177/0022022110396916

Barnard, A. (2008). Values, ethics and professionalization: A social work history. In A. Barnard, N. Horner \& J. Wild. Milton (Eds.), The value base of social work and social care: An active learning handbook. (p. 5-25). Milton Keynes: Open University Press.

Brown, D., \& Crace, R. K. (1996). Values in life role choices and outcomes: A conceptual model. The Career Development Quarterly, 44, 211-223.

Chu, K. H. L. (2008). A factorial validation of work value structure: second-order confirmatory factor analysis and its implications. Tourism Management, 29, 320-330.

Elizur, D. (1994). Gender and work values: A comparative analysis. The Journal of Social Psychology, 134, 201-212.

Feather, N.T. (2004). Value correlates of ambivalent attitudes toward gender relations. Personality and Social Psychology Bulletin, 30, 3-12. doi: $10.1177 / 0146167203258825$

Ginzberg, E., Ginsburg, S. W., Axelrad, S., \& Herma, J. L. (1951). Occupational choice: An approach to a general theory. New York: Columbia University Press.

Hendrix, V. L., \& Super, D. E. (1968). Factor dimensions and reliability of the Work Values Inventory. Vocational Guidance Quarterly, 17, 269-274. 
Jin, J., \& Rounds, J. (2011). Stability and change in work values: A meta-analysis of longitudinal studies. Journal of Vocational Behavior, 80, 326-339. doi: 10.1016/j.jvb.2011.10.007

Judge, T. A. \& Bretz, R. D. (1992).Effects of work values on job choice decisions. Journal of Applied Psychology, 77, 261-271.

Knafo, A. Roccas, S., \& Sagiv, L. (2011). The Value of Values in Cross Cultural Research: A Special Issue in Honor of Shalom Schwartz. Journal of Cross-Cultural Psychology, 42 (2), 178-185. doi:10.1177/0022022110396863

Miller, M. F. (1974). Relationship of vocational maturity to work values. Journal of Vocational Behavior, 5, 367-371.

Lyons, S. (2003). An exploration of generational values in life and at work. Unpublished PhD. thesis. Carleton University, Toronto, Canada.

Neuman, Y., Pizam, A., \&Reichel, A. (1980). Values as determinants of motivation: Tourism and other career choices. Annals of Tourism Research, 11, 428-442.

Ros, M., Schwartz, S. H., \& Surkiss, S. (1999). Basic individual values, work values, and the meaning of work. Applied Psychology: An International Review, 48, 49-71.

Ryckman, R. M. \& Houston, D. M. (2003).Value priorities in American and British female and male university students. The Journal of Social Psychology, 143, 127-138. 
Scannell, E. D., \& Allen, F. C. L. (2000). The Mehrabian Achieving Tendency Scale (MATS):

Reliability, validity and relationship to demographic characteristics. Current Psychology, 19, 301-311. doi: 10.1007/s12144-000-1022-8

Schmitt, N. (1996). Uses and abuses of coefficient alpha. Psychological Assessment, 8, 350-353.

Schwartz, S. H. (1992). Universals in the content and structure of values: Theoretical and advances and empirical tests in 20 countries. In M. P. Zanna (Ed.), Advances in Experimental Social Psychology, (Vol. 25, pp.1-63). San Diego, CA: Academic Press, Inc.

Schwartz, S. H. (1996). Value priorities and behavior: Applying a theory of integrated value systems. In C. Seligman, J. M. Olson, \& M. P. Zanna (Eds.), The psychology of values: The Ontario Symposium, (v 8, p.1-24). Hillsdale, N J: Erlbaum.

Schwartz, S. H., Melech, G., Lehmann, A., Burgess, Harris, M., \& Owens, V. (2001).

Extending the cross-cultural validity of the theory of basic human values with a different method of measurement. Journal of Cross-Cultural Psychology, 32, 519-542. doi:10.1177/0022022101032005001

Schwartz, S. H. \& Rubel, T. (2005). Sex differences in value priorities: Cross-cultural and multi-method studies. Journal of Personality and Social Psychology, 89, 1010-1028. doi:10.1037/0022-3514.89.6.1010 
Seligman, C., \& Katz, A. N. (1996). The dynamics of value system. In C. Seligman, J. M.

Olson, \& M. P. Zanna (Eds.), The Psychology of Values: The Ontario Symposium (v 8, pp. 53-75). Mahwah, NJ: Erlbaum.

Staats, S. (1981). Work Values Inventory scores from 1970 to 1980. Perceptual and Motor Skills, 53, 113-114.

Super, D. E. (1962). The structure of work values in relation to status, achievement, interests, and adjustment. Journal of Applied Psychology, 46, 231-239. doi: 10.1037/h0040109

Super, D.E. (1968). Manual for work values inventory. Boston, MA: Houghton Mifflin.

Super, D.E. (1995). Values: Their nature, assessment, and practical use. In D. E. Super \& B. Sverko (Eds.), Life roles, values, and careers: International findings of the Work Importance Study (pp.54-61). San Francisco: Jossey-Bass.

White, C. (2005). The relationship between cultural values and individual work values in the hospitality industry. International Journal of Tourism Research, 7, 221-229. doi: $10.1002 / j t r .535$

Wong, S. W. (2013). Assessing General and Work Values among University Students in Hong Kong. Unpublished EdD thesis: University of Hong Kong, Hong Kong, China.

Zaccaria, L., Mitchell, J., Creaser, J. \& Klehr, H. (1972). Work values of college-bound students. Psychological Reports, 31, 567-569. 
OPENNESS TO CHANGE

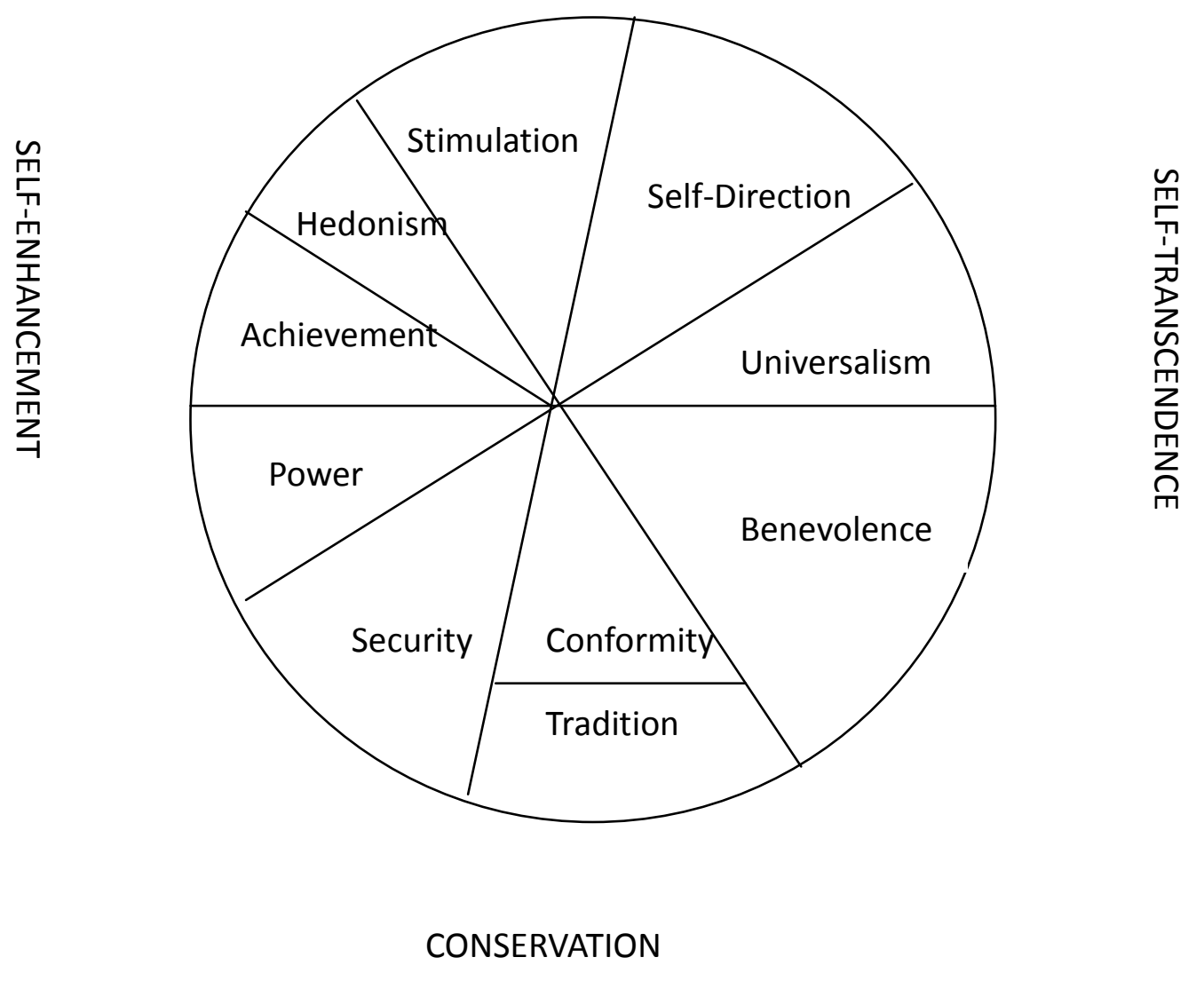

Figure 1. Schwartz's (1996) Universal Structure of Human Values System (p.5). 


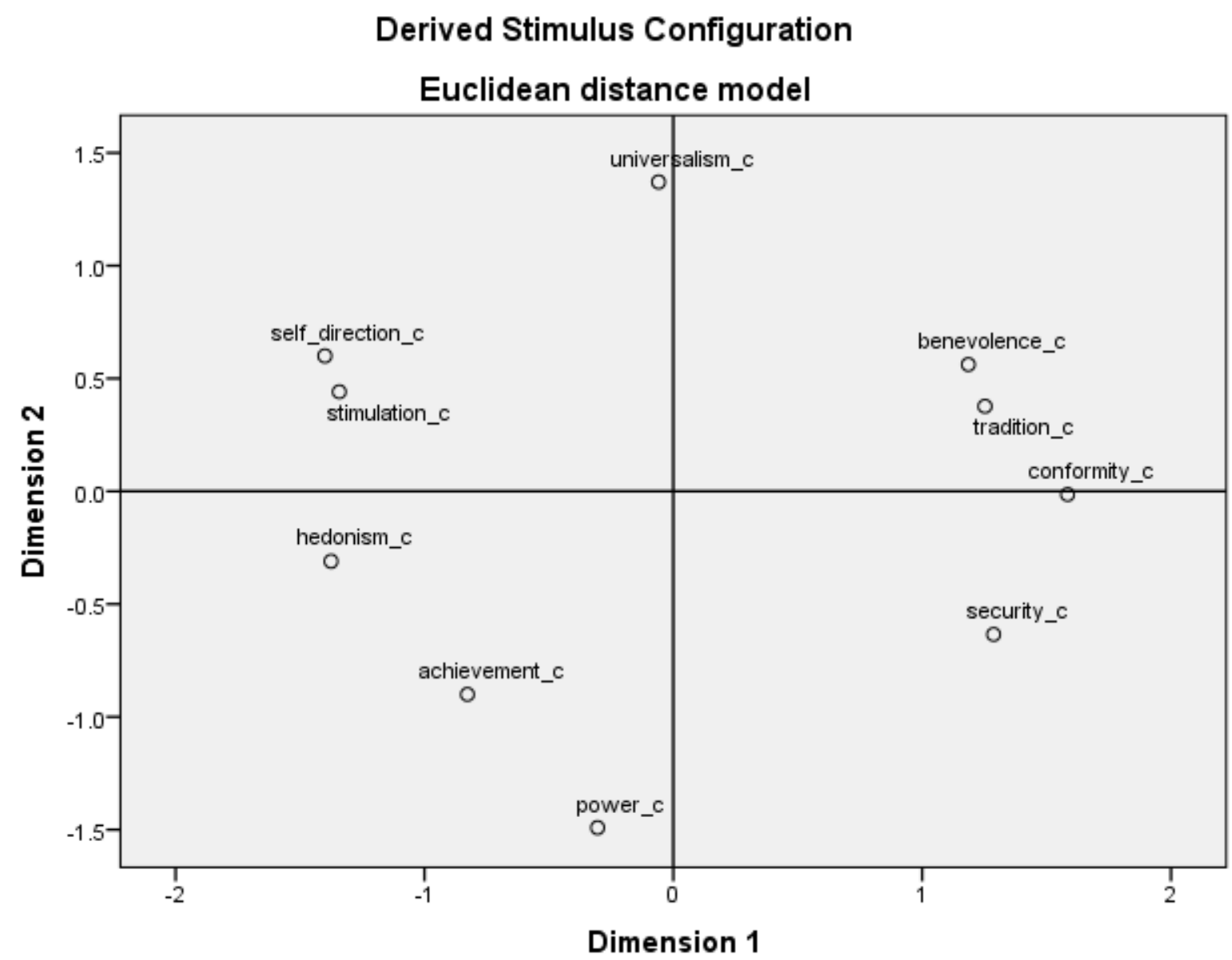

Figure 2. Multidimensional Scaling Map of the Relative Positions of SVS-58 Subscales of Social Work Students in Hong Kong

Notes: Based on SVS-58 centred sub-scales scores. N = 99; Kruskal's stress= .13769;

Stress and squared correlation (RSQ) $=0.87861$.

Table 1.

Comparison between Means for Social-Work and Non-Social-Work Students on Both Schwartz Values Survey and Work Values Inventory Subscales 


\begin{tabular}{|c|c|c|c|c|}
\hline \multirow[b]{2}{*}{ SVS Subscale } & \multirow{2}{*}{$\begin{array}{l}\text { Social Work } \\
\text { Students (N=99) } \\
\text { Mean } \\
\text { (Raw Scores) }\end{array}$} & \multirow{2}{*}{$\begin{array}{l}\text { Non-Social-Work } \\
\text { Students } \\
(\mathrm{N}=619) \\
\text { Mean } \\
\text { (Raw Scores) }\end{array}$} & \multicolumn{2}{|c|}{ Total $(\mathrm{N}=718)$} \\
\hline & & & Mean & $\begin{array}{l}\text { Cronbach's } \\
\text { Alpha }\end{array}$ \\
\hline Conformity & 4.4470 & 4.3957 & 4.4028 & 0.659 \\
\hline Tradition** & 3.9232 & 3.5725 & 3.6209 & 0.472 \\
\hline Benevolence** & 5.0707 & 4.7974 & 4.8351 & 0.720 \\
\hline Universalism*** & 4.8485 & 4.4720 & 4.5239 & 0.769 \\
\hline Self-Direction** & 4.8949 & 4.6853 & 4.7142 & 0.580 \\
\hline Stimulation & 3.5051 & 3.5983 & 3.5854 & 0.762 \\
\hline Hedonism & 4.4680 & 4.5439 & 4.5334 & 0.402 \\
\hline Achievement & 4.5556 & 4.4625 & 4.4753 & 0.660 \\
\hline Power & 3.2465 & 3.2336 & 3.2354 & 0.721 \\
\hline Security & 4.4424 & 4.5047 & 4.4961 & 0.604 \\
\hline \multicolumn{5}{|l|}{ WVI Subscale } \\
\hline Creativity** & 3.6020 & 3.3673 & 3.3993 & 0.882 \\
\hline Management & 3.0034 & 2.9687 & 2.9735 & 0.735 \\
\hline Achievement & 4.0067 & 3.9298 & 3.9404 & 0.387 \\
\hline Surroundings & 3.9933 & 4.0393 & 4.0330 & 0.590 \\
\hline $\begin{array}{l}\text { Supervisory } \\
\text { Relations* }\end{array}$ & 4.3737 & 4.2321 & 4.2516 & 0.781 \\
\hline Way of Life & 3.9192 & 3.9812 & 3.9726 & 0.396 \\
\hline Security & 3.6936 & 3.7781 & 3.7665 & 0.688 \\
\hline Associates & 3.9529 & 4.0296 & 4.0190 & 0.656 \\
\hline Aesthetics & 3.0135 & 2.9401 & 2.9503 & 0.460 \\
\hline Prestige & 3.5084 & 3.5293 & 3.5265 & 0.569 \\
\hline Independence* & 3.6566 & 3.4957 & 3.5179 & 0.536 \\
\hline Variety & 3.2694 & 3.1729 & 3.1862 & 0.717 \\
\hline $\begin{array}{l}\text { Economic } \\
\text { Returns* }\end{array}$ & 3.9798 & 4.1513 & 4.1277 & 0.793 \\
\hline Altruism*** & 4.0952 & 3.6349 & 3.6978 & 0.834 \\
\hline $\begin{array}{l}\text { Intellectual } \\
\text { Stimulation* }\end{array}$ & 3.5589 & 3.4023 & 3.4239 & 0.604 \\
\hline
\end{tabular}

Note. All t tests are two-tailed. ${ }^{*} \mathrm{p}<0.05 ;{ }^{* *} \mathrm{p}<0.01 ;{ }^{* * *} \mathrm{p}<0.001$

Table 2.

Gender Difference in Schwartz Values Survey and Work Values Inventory Subscale Scores among Social Work Students 


\begin{tabular}{lcc}
\hline & Male $(\mathrm{N}=30)$ & Female $(\mathrm{N}=69)$ \\
\hline $\begin{array}{l}\text { SVS Subscale } \\
\text { (Raw Scores) }\end{array}$ & Mean & Mean \\
\hline Conformity & 4.1500 & 4.5761 \\
Tradition* & 3.5600 & 4.0812 \\
Benevolence* & 4.7600 & 5.2058 \\
Universalism & 4.8750 & 4.8370 \\
Self-Direction & 5.0000 & 4.8493 \\
Stimulation & 3.7778 & 3.3865 \\
Hedonism & 4.6000 & 4.4106 \\
Achievement & 4.5083 & 4.5761 \\
Power & 3.1667 & 3.2812 \\
Security & 4.2067 & 4.5449 \\
\hline & & \\
WVI Subscale & & 3.6522 \\
\hline Creativity & 3.4828 & 2.9758 \\
Management & 3.0667 & 4.1304 \\
Achievement** & 3.7222 & 4.0918 \\
Surroundings* & 3.7667 & 4.5024 \\
Supervisory & 4.0778 & \\
Relations** & & 3.9855 \\
Way of Life & 3.7667 & 3.7633 \\
Security & 3.5333 & 4.0338 \\
Associates* & 3.7667 & 3.0145 \\
Aesthetics & 3.0111 & 3.5990 \\
Prestige* & 3.3000 & 3.7343 \\
Independence* & 3.4778 & 3.2657 \\
Variety & 3.2778 & 3.9565 \\
Economic & 4.0333 & \\
Returns & & \\
Altruism** & 3.8111 & \\
Intellectual & 3.5000 & \\
Stimulation & & \\
\hline Note. Allt & \\
\hline & & \\
\hline & & \\
\hline
\end{tabular}

Note. All t tests are two-tailed. ${ }^{*} \mathrm{p}<0.05 ;{ }^{* *} \mathrm{p}<0.01 ;{ }^{* * *} \mathrm{p}<0.001$

Table 3.

One-way ANOVA Results on Both Schwartz Values Survey and Work Values Inventory 
Subscales by Mode of Study

\begin{tabular}{|c|c|c|c|c|}
\hline & $\begin{array}{c}\text { 1.Full-timeBSW } \\
\text { student }(\mathrm{N}=37)\end{array}$ & $\begin{array}{c}\text { 2.Part-time } \\
\text { BSW } \\
\text { student }(\mathrm{N}=23)\end{array}$ & $\begin{array}{l}\text { 3.Part-time } \\
\text { MSW student } \\
(\mathrm{N}=39)\end{array}$ & \\
\hline $\begin{array}{l}\text { SVS Subscale } \\
\text { (Raw Scores) }\end{array}$ & Mean & Mean & Mean & Post Hoc Test \\
\hline Conformity & 4.4392 & 4.5978 & 4.3654 & \\
\hline Tradition & 3.7784 & 4.0261 & 4.0000 & \\
\hline Benevolence & 5.0054 & 4.9826 & 5.1846 & \\
\hline Universalism & 4.6723 & 4.9402 & 4.9615 & \\
\hline Self-Direction & 4.8216 & 4.8087 & 5.0154 & \\
\hline Stimulation & 3.4955 & 3.1304 & 3.7350 & \\
\hline Hedonism & 4.2342 & 4.6377 & 4.5897 & \\
\hline Achievement & 4.4797 & 4.5543 & 4.6282 & \\
\hline Power & 3.0054 & 3.6348 & 3.2462 & \\
\hline Security & 4.2378 & 4.6522 & 4.5128 & \\
\hline \multicolumn{5}{|l|}{ WVI Subscale } \\
\hline Creativity & 3.5676 & 3.6377 & 3.6140 & \\
\hline Management & 2.8559 & 3.1449 & 3.0598 & \\
\hline Achievement & 4.0360 & 4.0435 & 3.9573 & \\
\hline Surroundings & 4.0270 & 4.0435 & 3.9316 & \\
\hline $\begin{array}{l}\text { Supervisory } \\
\text { Relations }\end{array}$ & 4.3063 & 4.5652 & 4.3248 & \\
\hline Way of Life* & 4.0991 & 3.7391 & 3.8547 & $1>2 ; 1>3$ \\
\hline Security & 3.6036 & 3.9420 & 3.6325 & \\
\hline Associates* & 4.1441 & 3.7826 & 3.8718 & $1>2 ; 1>3$ \\
\hline Aesthetics & 2.9730 & 3.0725 & 3.0171 & \\
\hline Prestige & 3.5405 & 3.3913 & 3.5470 & \\
\hline Independence & 3.6036 & 3.6812 & 3.6923 & \\
\hline Variety* & 3.1622 & 3.0580 & 3.4957 & $3>1 ; 3>2$ \\
\hline $\begin{array}{l}\text { Economic } \\
\text { Returns }\end{array}$ & 3.9820 & 4.1449 & 3.8803 & \\
\hline Altruism & 4.1532 & 3.9565 & 4.1228 & \\
\hline $\begin{array}{l}\text { Intellectual } \\
\text { Stimulation }\end{array}$ & 3.4144 & 3.5217 & 3.7179 & \\
\hline
\end{tabular}

Notes. Group means compared by ANOVA and LSD Post Hoc tests. ${ }^{*} \mathrm{p}<0.05 ;{ }^{* *} \mathrm{p}<0.01 ;{ }^{* * *} \mathrm{p}<0.001$ 1= Full-time BSW students; 2= Part-time BSW students; 3= Part-time MSW students 